\title{
AIRBORNE FUNGI IN DWELLINGS FOR DAIRY COWS AND LAYING HENS*
}

\author{
Kristina MATKOVIĆ ${ }^{1}$, Marija VUČEMILO ${ }^{1}$, and Bara VINKOVIĆ ${ }^{2}$ \\ Department of Animal Hygiene, Environment and Ethology, Faculty of Veterinary Medicine, University of Zagreb ${ }^{1}$, \\ Laboratory for Ecology, Croatian Veterinary Institute', Zagreb, Croatia
}

Received in April 2009

Accepted in August 2009

\begin{abstract}
The air of animal dwellings can contain great amounts of bioaerosol composed of dust, bacteria, fungi, and endotoxins. The composition may depend on animal species, building construction, animal accommodation, and microclimate parameters, to name just a few factors. Pathogens contained may be a serious threat to animal and human health.

The aim of our study was to analyse the fungi aerosol content in a stable housing dairy cows and in a coop for laying hens over the three autumn months of 2007. The air was sampled on Petri dishes with Sabouraud glucose agar. After laboratory treatment, we identified the most common fungi. Their count in the stable ranged from $3.98 \times 10^{3} \mathrm{CFU} \mathrm{m}{ }^{-3}$ to $5.11 \times 10^{4} \mathrm{CFU} \mathrm{m}^{-3}$ and in the coop from $6.89 \times 10^{4} \mathrm{CFU} \mathrm{m}^{-3}$ to $1.13 \times 10^{5} \mathrm{CFU} \mathrm{m}{ }^{-3}$. The difference between the two animal dwellings was statistically different at the level of $\mathrm{p}<0.05$. In both dwellings, the most common were the fungi Aspergillus sp., Penicillium sp., and yeasts, followed by Cladosporium sp., Fusarium sp., Mucor sp., Scopulariopsis sp., Alternaria sp., and Rhizopus sp.

Our results are entirely in line with values reported in literature and are at the lower end of the range. They call for further investigation that would eventually lead to setting air quality standards for animal dwellings and to developing reliable monitoring systems in order to ensure safe food and safe environment.
\end{abstract}

KEY WORDS: air hygiene, airborne microorganisms, animal housing, environment

The air of animal dwellings can have considerable amounts of bioaerosols containing dust, bacteria, fungi, and endotoxins. Their composition depends on the type of construction, animal population, temperature, moisture, and activities performed indoors such as feeding, milking, and collecting eggs.

Intensive animal production is a significant source of air contaminants that may greatly influence animal health and production. In addition, it may also pose occupational and environmental health risk (1-3). The air in any housing type is contaminated

\footnotetext{
The subject was presented at the $2^{\text {nd }}$ Croatian Scientific Symposium with International Participation Fungi and Mycotoxins - Health Aspects and Prevention, held in Zagreb, Croatia on 5 December 2008.
}

with various microorganisms and gases. In addition to the mechanical effects, these pollutants may cause infection, affect the immune system or cause allergies in animals and humans. These effects may be additionally aggravated by poor microclimate, the temperature-humidity complex in particular.

Saprophytes are the most common in these settings, but they may also contain pathogenic bacteria, fungi, and viruses. Eighty percent of the fungi found in animal dwellings air belong to the Aspergillus sp. and Penicillium sp., followed by Fusarium sp., Cladosporium sp., Mucor sp., and Alternaria sp. (4).

The aim of our study was to analyse the content and the composition of fungi in indoor air of a stable 
housing dairy cows and of a laying hen coop, and to establish indoor temperature and humidity as the basic microclimate indicators. This study continues our investigation of airborne pollutants whose aim is to establish acceptable levels and composition of airborne fungi in animal dwellings.

\section{MATERIAL AND METHODS}

The stable was $6 \mathrm{~m} \times 8 \mathrm{~m} \times 3 \mathrm{~m}$, classically built, and accommodating 12 cows. The cows stayed in the stable all day long, received the usual fodder (hay, haylage, and concentrate), and were milked twice a day. Milk was instantly taken to the collection point, because this husbandry did not have a cooling device. Fungi were measured at three spots in the feeding corridor.

The coop consisted of conventional cages housing about 17,000 Shaver hybrid laying hens. Feeding, watering, ventilation, lighting, and manure removal were regulated automatically. Fungi measurements started at week 25 of production. Air was sampled at five spots at the second floor level along the central corridor.

Measurements in both dwellings were done 12 times, once a week, between 8:00 $\mathrm{h}$ and 12:00 $\mathrm{h}$ in the morning, for three months. Ten-litre air samples for determining the fungi content were collected using the air sampler MAS-100 (Merck KgaA, Darmstadt, Germany). Airborne particles were collected on Petri dishes ( $9 \mathrm{~cm}$ in diameter) with a commercially available Sabouraud glucose agar (Biolife, Milan, Italy) and incubated at $22^{\circ} \mathrm{C}$ for 5 days in a incubator. Grown colonies $\left(\mathrm{CFU} \mathrm{m}{ }^{-3}\right)$ were counted using a digital colony counter (Selecta, Spain).

Fungal species were identified by their culture properties and micromorphology. Air temperature $\left({ }^{\circ} \mathrm{C}\right)$, relative humidity $(\%)$ and airflow rate $\left(\mathrm{m} \mathrm{s}^{-1}\right)$ were determined using a TESTO device (Testo Inc., Lenzkirch, Germany).

For statistical analysis we used Microsoft Excel and Statistica 7 software, and it included descriptive statistics and Wilcoxon's test. The level of significance was set at $\mathrm{p}<0.05$.

\section{RESULTS AND DISCUSSION}

Reports of air concentrations of microorganisms in poultry housing greatly vary, which may to some extent be related to different sampling methods used in different studies. The concentration of airborne microorganisms in layer housing reported by Hartung (5) ranged from 360 to 3,781 colony forming units per litre $\left(\mathrm{CFU} \mathrm{L}^{-1}\right)$ of air, and by Müller (6) between $17 \mathrm{CFU} \mathrm{L}^{-1}$ and 5,860 $\mathrm{CFU} \mathrm{L}^{-1}$ air. Seedorf et al. (7) reported that the total airborne microorganism concentration in animal housing ranged from $8.3 \log \mathrm{CFU} \mathrm{h}^{-1}$ per $500 \mathrm{~kg}$ body weight (b.w.) in layer houses to $6.5 \log \mathrm{CFU} \mathrm{h}^{-1}$ per $500 \mathrm{~kg}$ b.w. in yearling cattle and milk cow housings. The emission of fungi ranged from $7.7 \log \mathrm{CFU} \mathrm{h}^{-1}$ per $500 \mathrm{~kg}$ b.w. in broiler housing through $5.8 \log \mathrm{CFU} \mathrm{h}^{-1}$ per $500 \mathrm{~kg}$ b.w. in weaned piglet housing. Wathes (8) says that usually there are more than $10^{9} \mathrm{CFU} \mathrm{m}^{-3}$ of fungi in the air of animal dwellings. Eduard (9) reports that the total count of fungi in a cattle barn can reach $10^{5} \mathrm{CFU} \mathrm{m}^{-3}$.

Cows are not as susceptible to environmental influences as other farm animals. Their optimal ambient temperature is between $5{ }^{\circ} \mathrm{C}$ and $20^{\circ} \mathrm{C}$ at relative humidity between $60 \%$ and $80 \%(10,11)$ and air flow preferably exceeding $0.30 \mathrm{~m} \mathrm{~s}^{-1}$. In contrast, the optimum air temperature for laying hens is between $15{ }^{\circ} \mathrm{C}$ and $22{ }^{\circ} \mathrm{C}(12)$. Temperature outside these limits significantly decreases or can entirely stop egg production. Optimal relative humidity for hens is around $65 \%$ (13).

Fungi counts depend on the sampling method and refer to live fungi. Fungi viability in turn depends on the microclimate, especially on relative humidity. At $55 \%$ to $75 \%$, most of the fungi can survive for a short time (14).

Ventilation system is the most responsible for air quality in animal dwellings. Objects with artificial microclimate such as layer housings are expected to have a higher number of airborne microorganisms. Microclimate in our dwellings were in the recommended range for these animals (15). Moreover, concentrations of ammonia and carbon dioxide were below reports in literature $(16,17)$. This suggests good building construction and ventilation system.

Our comparison has shown a statistically significant difference in air quality between the stable and the coop with the conventional cage system (Table 1), particularly in respect to the fungi content, air flow, and ammonia and carbon dioxide concentrations $(\mathrm{p}<0.05)$. These results are consistent with international data, where fungi counts in animal dwellings range between $10^{3} \mathrm{CFU} \mathrm{m}^{-3}$ and $10^{9} \mathrm{CFU} \mathrm{m}^{-3}(5,7-9,18$ - 
Table 1 Mean counts of airborne fungi and microclimate parameters in animal dwellings

\begin{tabular}{|c|c|c|c|c|c|c|c|}
\hline \multirow{2}{*}{ Parameters } & \multirow{2}{*}{$\mathrm{n}$} & \multicolumn{3}{|c|}{ Dairy stable } & \multicolumn{3}{|c|}{ Layer coop } \\
\hline & & September & October & November & September & October & November \\
\hline Fungi / CFU m ${ }^{-3}$ & 12 & $3.98 \times 10^{3(\mathrm{a})}$ & $4.12 \times 10^{4(a)}$ & $5.11 \times 10^{4}$ & $6.89 \times 10^{4(\mathrm{~b})}$ & $7.13 \times 10^{4(b)}$ & $1.13 \times 10^{5(b, c)}$ \\
\hline Air temperature $/{ }^{\circ} \mathrm{C}$ & 12 & 18.4 & 17.4 & 15.3 & 18.9 & 17.9 & 17.1 \\
\hline $\begin{array}{l}\text { Relative } \\
\text { humidity / \% }\end{array}$ & 12 & 74.5 & 62.7 & 62.5 & 65.9 & 62.8 & 68.8 \\
\hline Air flow / $\mathrm{m} \mathrm{s}^{-1}$ & 12 & $0.20^{\mathrm{a}}$ & $0.21^{\mathrm{a}}$ & $0.16^{\mathrm{a}}$ & $0.08^{\mathrm{b}}$ & $0.07^{\mathrm{b}}$ & $0.08^{\mathrm{b}}$ \\
\hline Ammonia / \% & 12 & $0^{\mathrm{a}}$ & $0^{\mathrm{a}}$ & $0^{\mathrm{a}}$ & $0.0011^{\mathrm{b}}$ & $0.0010^{\mathrm{b}}$ & $0.0011^{\mathrm{b}}$ \\
\hline Carbon dioxide / \% & 12 & $0.06^{\mathrm{a}}$ & $0.09^{\mathrm{a}}$ & $0.07^{\mathrm{a}}$ & $0.12^{\mathrm{b}}$ & $0.17^{\mathrm{b}}$ & $0.18^{\mathrm{b}}$ \\
\hline Lighting / lx & 12 & 20 & 22 & 23 & 17 & 21 & 19 \\
\hline
\end{tabular}

$n=$ number of measurements; $C F U=$ colony forming unit; ${ }^{a, b, c}=$ arithmetic means that do not share the same letter in superscript were statistically significantly different at $p<0.05$

20). Comparable results have also been reported by Croatian authors $(11,21-23)$. The dominant species in our study, that is, Aspergillus, Penicillium, and yeasts (Table 2) confirm other reports $(4,5,7,19,24)$. Both the species and the levels of exposure to them raise a certain concern for the health of animals and humans who in these dwellings $(25,26)$. This will be the subject of further investigation.

Table 2 Most common airborne fungi

\begin{tabular}{|l|c|c|}
\hline Fungi & $\begin{array}{c}\text { Dairy stable } \\
\mathbf{\%}\end{array}$ & $\begin{array}{c}\text { Layer coop } \\
\mathbf{\%}\end{array}$ \\
\hline Alternaria $\mathrm{sp}$. & 0.50 & 0.50 \\
\hline Aspergillus $\mathrm{sp}$. & 31.00 & 30.00 \\
\hline Cladosporium $\mathrm{sp}$. & 2.60 & 5.00 \\
\hline Fusarium $\mathrm{sp}$. & 6.30 & 8.30 \\
\hline Yeasts & 23.00 & 22.00 \\
\hline Mucor sp. & 2.30 & 1.30 \\
\hline Penicillium $\mathrm{sp}$. & 25.00 & 25.00 \\
\hline Rhizopus $\mathrm{sp}$. & 8.00 & 7.83 \\
\hline Scopulariopsis $\mathrm{sp}$. & 1.30 & 0.07 \\
\hline
\end{tabular}

\section{CONCLUSION}

The levels and the spectrum of airborne fungi in the investigated dwellings were at the lower end of ranges reported in literature. Our findings call for further investigation that would eventually lead to setting air quality standards for animal dwellings and to developing reliable monitoring systems in order to ensure safe food and safe environment.

\section{Acknowledgments}

This study was a part of a scientific project "Environmental Effects on Animal Health and Safety of Foods of Animal Origin", supported by the Ministry of Science, Education and Sports of the Republic of Croatia, grant No. 053-0531854-1867.

\section{REFERENCES}

1. Donham KJ, Cumro D. Setting maximum dust exposure levels for people and animals in livestock facilities. In: Proceedings of the International Symposium on Dust Control in Animal Production Facilities; 30 May - 2 June 1999; Aarhus, Denmark. Horsens: Danish Institute of Agricultural Sciences; 1999. p. 93-110.

2. Donham KJ, Cumro D, Reynolds S. Synergistic effects of dust and ammonia on the occupational health effects of poultry production workers. J Agromedicine 2002;8:57-76.

3. Whyte RT. Occupational exposure of poultry stockmen in current barn systems for egg production in the United Kingdom. Br Poult Sci 2002;43:364-73.

4. Hartung J. Emissionen luftgetragener Stoffe aus Nutztierställen [Emissions of airborne substances from stalls of domestic animals, in German]. Pneumologie 1992;46:196-202.

5. Hartung J. The effect of airborne particulates on livestock health and production. In: Dewi I, Axford RFE, Mara I, Omed $\mathrm{H}$, editors. Pollution in livestock systems. Wallingford: CAB International; 1994. p. 55-69.

6. Müller W. Dust and microbial emissions from animal production: Origin, quantity and quality of microbial emissions in animal houses. In: Strauch D, editor. Animal Production and Environmental Health. Volume B6. Amsterdam: Elsevier Science Publishers; 1987. p. 47-74.

7. Seedorf J, Hartung J, Schroder M, Linkert KH, Holden MR, Sneath RW, Short JL, White RP, Pederson S, Takai H, Johnsen JO, Metz JHM, Groot Koerkamp PWG, Uenk 
GH, Wathes CM. Concentrations and emissions of airborne endotoxins and microorganisms in livestock buildings in Northern Europe. J Agr Eng Res 1998;70:97-109.Wathes CM. Air and surface hygiene. In: Wathes CM, Charles DR, editors. Livestock housing. Wallingford: CAB International; 1994. p. 123-48.

8. Eduard W. Exposure to non-infectious microorganisms and endotoxins in agriculture. Ann Agric Environ Med 1997:4:179-86

9. Kadzere CT, Murphy MR, Silanikove N, Maltz E. Heat stress in lactating dairy cows: a review. Livest Prod Sci 2002;77:5991.

10. Matković K, Vučemilo M, Vinković B, Šeol B, Pavičić Ž, Tofant A, Matković S. Effect of microclimate on bacteria count and airborne emission from dairy barns on the environment. Ann Agric Environ Med 2006;13:349-54.

11. Mužic S. Proizvodnja kokošjih jaja [Production of chicken eggs, in Croatian]. Zagreb: Biblioteka Poljoprivredni savjetnik. Hrvatski zadružni savez; 1999.

12. Tüller R, Allmendinger A. Geflügelställe: Stallbau, Klima, Einrichtung [Poultry dwellings: object building, climate, equipment, in German]. Stuttgart: Eugen Ulmer Verlag, 1990.

13. Bickert W. Ventilation and animal health. Agricultural Engineering Department. Michigan State University Newsletter 2001 [displayed 22 October 2009] Available at http:/www.egr.msu.edu/age/documents/news archives/eco/ ventilation.pdf.

14. Vučemilo M, Matković K, Vinković B, Macan J, Varnai VM, Prester Lj, Granić K, Orct T. Effect of microclimate on the airborne dust and endotoxin concentration in a broiler house. Czech J Anim Sci 2008;53:83-9.

15. Anderson N, Strader R, Davidson C. Airborne reduced nitrogen: ammonia emissions from agriculture and other sources. Environ Int 2003;29:277-86.

16. Braam CR, Swierstra D. Volatilization of ammonia from dairy housing floors with different surface characteristics. J Agric Eng Res 1999;72:59-69.

17. Hartung J. Gas und partikelförmige emissionen aus ställen der tierproduktion [Gas and particle emissions from housing in animal production, in German]. Dtsch Tierärztl Wochenschr 1995; 102:283-8.

18. Duchaine C, Meriaux A, Brochu G, Cormier Y. Airborne microflora in Quebec dairy farms: lack of effect of bacterial hay preservatives. Am Ind Hyg Assoc J 1999;60:89-95.

19. Seedorf J. An emission inventory of livestock-related bioaerosols for Lower Saxony, Germany. Atmos Environ 2004;38;6565-81

20. Vinković B, Vučemilo M, Matković K, Rajković Janje R. Prilog procjeni utjecaja staje muznih krava na kvalitetu lokalnog okoliša [Toward a estimate an influence of dairy cows stables on local environment quality, in Croatian]. In: Kos J, editor. Proceedings of the IV ${ }^{\text {th }}$ Midleeurope Buatric Congress; 23-27 April 2003; Lovran, Croatia. Zagreb: Faculty of Veterinary Medicine; 2003. p. 301-5.

21. Vinković B, Vučemilo M, Matković K, Matković S. Bakterije - pokazatelji kvalitete zraka u stajskom uzgoju goveda [Bacteria - air quality indicators in stable breeding of cattle, in Croatian]. In: Vinković B, editor. Proceedings of the 5th scientific meeting in DDD with international participation "Reliable way to healthy animals, human and their environment"; 5-8 May 2004; Mali Lošinj, Croatia. Zagreb: Faculty of Veterinary Medicine; 2004. p. 535-40.

22. Gutzmirtl D, Kralik G, Vučemilo M, Vinković B, Žurić M, Matković K. Nalaz bakterija u zraku tovilišta svinja: kriterij za procjenu utjecaja farme na kvalitetu okoliša [Bacteria in air of pig feedlot: a criterion for estimation of farm influence on environment quality, in Croatian]. Stočarstvo 2004;58:363-6.

23. Matković K, Vučemilo M, Vinković B, Šeol B, Pavičić Ž, Matković S. Qualitative structure of airborne bacteria and fungi in dairy barn and nearby environment. Czech J Anim Sci 2007:52:249-53.

24. Radon K, Opravil U, Hartung J, Szadkowski D, Nowak D. Work-related respiratory disorders and farming characteristics among cattle farmers in Northern Germany. Am J Ind Med 1999;36:444-9

25. Radon K, Danuser B, Iversen M, Monso E, Weber C, Hartung J, Donham KJ, Palmgren U, Nowak D. Air contaminants in different European farming environments. Ann Agric Environ Med 2002;9:41-8. 


\section{Sažetak}

\section{GLJIVICE KAO SASTAVNI DIO BIOAEROSOLA U NASTAMBAMA ZA MUZNE KRAVE I NESILICE KONZUMNIH JAJA}

U zraku nastambi za držanje životinja stvaraju se znatne količine bioaerosola. Njega čine prašina, bakterije, gljivice, endotoksini i plinovi. Brojnost im ovisi o građevinsko-tehničkim značajkama nastambi, naseljenosti životinjama, načinu držanja, temperaturno-vlažnim odnosima u staji i aktivnostima oko hranjenja, mužnje, skupljanja jaja i drugih poslova. Ove čestice, ako su patogene, mogu biti ozbiljna prijetnja za zdravlje ljudi.

Mjerenja su obavljana u staji muznih krava te u objektu za nesilice, 2007. godine, tijekom tri jesenja mjeseca.

Zrak je uzorkovan na Petrijeve zdjelice sa Sabouraudovim glukoznim agarom, uređajem MAS 100. Nakon obrade u laboratoriju, prema osnovnim i mikromorfološkim osobinama poraslih kolonija identificirani su najčešće zastupljeni rodovi gljivica.

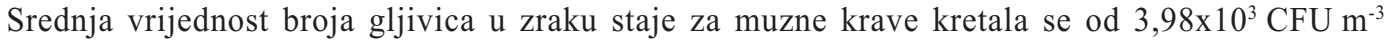
do $5,11 \times 10^{4} \mathrm{CFU} \mathrm{m^{-3 }}$. Broj gljivica u zraku objekta za nesilice kretao se od $6,89 \times 10^{4} \mathrm{CFU} \mathrm{m}^{-3}$ do $1,13 \times 10^{5} \mathrm{CFU} \mathrm{m}^{-3}$. Ove vrijednosti statistički su se značajno razlikovale na razini $\mathrm{p}<0,05$.

U obje pretraživane nastambe najčešće su bili zastupljeni rodovi Aspergillus, Penicillium i kvasnice. U manjem postotku utvrđene su gljivice iz rodova Cladosporium sp., Fusarium sp., Mucor sp., Scopulariopsis sp., Alternaria sp. i Rhizopus sp.

Rezultati ovih istraživanja o kvantitativnom i kvalitativnom sastavu gljivica u zraku pretraženih nastambi potpuno su u skladu s vrijednostima zabilježenim u literaturi te se nalaze na donjim granicama opisanih raspona. Utvrđeni broj i rodovi gljivica ukazuju na nužnost daljnjih istraživanja te potrebu postavljanja standardnih vrijednosti glede kvalitete zraka u nastambama za životinje, kao i razvoj vjerodostojnog sustava praćenja navedenih čimbenika, s ciljem stvaranja sigurne hrane i sigurnog okoliša.

KLJUČNE RIJEČI: higijena zraka, mikroorganizmi iz zraka, okoliš, smještaj životinja

\section{CORRESPONDING AUTHOR:}

Kristina Matković, $\mathrm{PhD}$

Faculty of Veterinary Medicine, University of Zagreb Department of Animal Hygiene, Environment and Ethology Heinzelova 55, 10000 Zagreb, Croatia E-mail:kmatkov@vef.hr 